\title{
Pre-Service Teacher Career Choice Motivation: A Comparison of Vocational Education and Training Teachers and Comprehensive School Teachers in Germany
}

\author{
Anne Stellmacher*, Svenja Ohlemann, Jan Pfetsch, Angela Ittel \\ Technische Universität Berlin, Institute of Education, Department of Educational Psychology, \\ Marchstraße 23, 10587 Berlin, Germany
}

Received: 06.03.2019, Accepted: 30.01.2020, Published: 18.08.2020

\begin{abstract}
Context: The current shortage of teachers in Germany, especially in vocational schools, is of relevance to the education system and labour market policy. To recruit future teachers more effectively, it is of great importance to gain a better understanding of pre-service teachers' career choice motivation. However, research has concentrated so far mainly on teachers in the general education system. The present study investigates the career choice motivation of students who will become vocational education and training (VET) teachers and compares it to the career choice motivation of future comprehensive school teachers.

Approach: We surveyed $N=79$ teacher training students in total, 30 pre-service VET teachers and 49 pre-service comprehensive school teachers at the beginning of their university-based teacher training. To measure career choice motivation, we used the standardized questionnaire Motivation for Choosing Teacher Education (FEMOLA) including six subscales (Pohlmann \& Möller, 2010). In order to compare pre-service VET and comprehensive school teachers with regard to the six scales of career choice motivation, we performed a multivariate analysis of covariance (MANCOVA).
\end{abstract}

*Corresponding author: anne.stellmacher@tu-berlin.de 
Findings: We found the highest means for the motives subject-specific and educational interest for the future VET teachers. In comparison to the pre-service comprehensive school teachers, they rated their educational interest, social influences, and utility as significantly less relevant in terms of their career choice motivation. There are no significant differences on the other three motivational scales.

Conclusion: The findings show that the two groups partially differ in their motivations to become a teacher. Therefore, we can conclude that the measures for attracting new students should also be individually adapted to the motives for their career choice. For example, in a counselling interview, the motives for choosing a profession should be discussed and compared with the requirements for studying and later working life.

Keywords: Career Choice Motivation, Vocational Education and Training, VET, Pre-Service Vocational Teacher, Recruiting, Multivariate Analysis of Covariance, MANCOVA

\section{Introduction}

The cognitive, social and emotional development of children is strongly shaped by their learning experiences in schools. Within the educational system teachers play a central role by designing learning opportunities. The professional role and competencies of teachers are closely connected to students' achievement (Hattie, 2009), underlining the importance of well-educated and skilled teachers in schools. However, similar to many countries around the world like Australia, the U.S., or several European countries (Watt et al., 2012), Germany currently faces a shortage of teaching staff, equally in general and vocational education schools (Bertelsmann Stiftung, 2017). Especially for vocational schools the problem becomes acute as not enough people decide to become a vocational school teacher. And this teacher shortage particularly applies to industrial-technical and nursing professions (Kultusministerkonferenz [KMK], 2011; Lange \& Sülflow, 2017). In Germany, only 50\% of the predicted demand for vocational school teachers will be covered during the period of the school years 2016/17 and 2020/21 (Klemm, 2018). Possible causes include that teaching at vocational schools is little known as a profession, and, in addition, despite its generally positive image not as attractive as teaching at general education schools (Frommberger \& Lange, 2018; Huismann, 2018). Compared to teachers at other school types, such as the high academic school track (Gymnasium), teachers at vocational schools might receive less prestige, less remuneration and might be seen as "blue collar" teachers, all adding up to a slightly lower attractiveness of teaching in vocational schools. To comply with the challenge of recruiting more people for teacher training to overcome the above-mentioned lack, we need to know where and how to find further potential applicants. One important angle to consider on that note are the motives why students chose the profession of vocational education and training (VET) teacher in the 
first place (Driesel-Lange et al., 2017). However, their career choice motivation-understood as the factors or reasons that are influential for the decision to choose teaching as a career (Han \& Yin, 2016; Thomson et al., 2012; Watt et al., 2012; Wenström et al., 2018)—is little studied so far.

In this study we therefore examine pre-service VET teachers' career choice motivation. A high proportion of them completed a vocational training themselves before entering their teacher training and their share in VET teacher training is far higher than it is in general education teacher training (Stellmacher et al., 2019). Future VET teachers thus part from a different starting point than those in the general teaching profession. It can be further assumed that their professional experience gained during vocational training leads to a different weighting of the career choice motives.

This is why we also compare the motivation of pre-service VET teachers to those of future general school teachers, more specifically to those who will teach at a comprehensive school (Integrierte Sekundarschule). We aim to shed light on possible differences between these two groups in order to be able to shape future recruiting strategies to their specific career motivations. Our research therefore addresses two gaps in the existing literature: First, we analyze what motivates persons to start their training in order to become VET teachers. Second, we compare their motives to pre-service comprehensive school teachers, and address the specificity and commonalities between both groups. There is paucity of research on both research topics. The results might help to decide whether and which specific recruitment strategies for pre-service VET teachers can be more successful than those of the status quo.

Before presenting our study, we will describe vocational education and training in Germany as well as the course of training to become a VET teacher. We then concentrate on career choice and career motivation and give a brief overview of the current state of research.

\section{Vocational Education and Training in Germany}

VET systems exist in almost all European countries. They strongly differ in terms of their characteristics. In a survey, the European Centre for the Development of Vocational Training ([Cedefop], 2017) found 30 different VET concepts in Europe. However, within this variety, they identified four ways of how VET is understood: (1) As work-based or dual initial training, (2) as initial vocational education, (3) as further training, or (4) as (part of) lifelong learning. Apprenticeship programmes, also known as dual system, belong to the first of the above-described groups and build the main pillar of the German VET system. 


\subsection{The Dual System}

The dual system consists of two learning venues or learning places: Companies of the according industry or occupational field and vocational schools. $70 \%$ of the two-year or three-year training programme is work-based. Students typically work three to four days at their apprenticing company. The apprentices are employed by the company and receive a salary that is regulated by collective agreement and is increased with each year during the training period. Companies may only employ apprentices if they can fulfil a set of standard qualifications (Hippach-Schneider \& Huismann, 2019). ${ }^{1}$

The other $30 \%$ of the dual programme are school-based. Students spend the other one or two days within a week at their vocational school (ibid.). The vocational school fulfils the task of imparting basic vocational education and vocational training and extending the previously acquired general education. Due to the frequent alternation between theoretical and practical training phases within the dual system, apprentices quickly gain professional experience and knowledge, while getting a realistic perspective on the daily work life in their profession from the very beginning (Blaß \& Himmelrath, 2016). Hippach-Schneider and Huismann (2019) summarize the core of the German VET systems as a "cooperation between state, companies, and social partners, who set together national standards and training regulations (for both learning places)" (p. 14). Both institutions-vocational schools and companies-fulfil this joint educational and pedagogical mission as equal partners. The successful completion of training, both at the vocational school and at the company, qualifies the graduate to exercise a profession as specialist (ibid.). Currently, there are 327 recognized VET occupations in the fields of industry and commerce, crafts, agriculture as well as in the liberal professions, public service, home economics, and health care (Federal Institute for Vocational Education and Training [BIBB], 2018).

In addition to the dual system, there are other VET programmes in Germany, such as full-time and part-time school-based vocational trainings, e.g. in the sectors commercial, languages, crafts, health care, or nutrition, which take between one year and three years to complete. Another type of VET are transition programmes ${ }^{2}$ which aim to support students in their professional orientation and prepare them to start further training. Participants in transition programmes often suffer from social disadvantages, insufficient German language skills, learning difficulties, and other impairments (Hippach-Schneider \& Huismann, 2019).

\footnotetext{
These regulations also ensure a uniform national standard (Hippach-Schneider \& Huismann, 2019).

2 Transition programmes include the pre-vocational training year (BVJ), the basic vocational training year (BGJ) and the introductory training $(\mathrm{EQ})$.
} 


\subsection{Training of Future VET Teachers}

In the dual system, there are in-company trainers and VET school teachers, who have different responsibilities and tasks. In-company trainers accompany the apprentice's practical training at the workplace. VET school teachers impart theoretical knowledge. Due to the wide range of VET programmes addressing different target groups, there are some teachers and trainers who are specialised to teach certain groups or in specific settings: VET teachers and trainers who lead disabled persons to a dual system diploma, VET teachers for full-time vocational schools, and learning facilitators (Hippach-Schneider \& Huismann, 2019).

In Germany, the VET teacher training is regulated by the Conference of Ministers of Education and Cultural Affairs (KMK) and is sectioned into two phases ${ }^{3}$ : A first phase taking place at university focusses on the theoretical education (Hippach-Schneider \& Huismann, 2019). It is followed by the second phase, the preparatory practical service, also called the probationary period (Referendariat ${ }^{4}$ ) emphasising on the practical learning (Hippach-Schneider \& Huismann, 2019). University education should consider both scientific findings and professional practice, it should further enable prospective teachers to apply their professional and pedagogical competence (KMK, 2016). Students who aim to become VET teachers usually combine a vocational subject, e.g. economy and administration, health science, electrical engineering, or information technology, with a general educational subject, such as mathematics or biology (Frommberger \& Lange, 2018). The study program comprises scientific subject-related, didactic, and pedagogical components, as well as first practical experiences, both at a vocational school and within a company (Hensen \& Hippach-Schneider, 2016). After a standard study period of 4.5 to 5 years, graduates receive a Master of Education or the First State Examination (named erstes Staatsexamen). During the subsequent Referendariat the aspiring teachers continue their education by applying the scientific education to real-life situations (KMK, 2016). In this phase, the prospective teachers are to be prepared for their work and their responsibility as teachers and educators. In supplementary seminars, usually conducted by VET teachers holding an additional qualification, their professional, pedagogical, and psychological training continues (Frommberger \& Lange, 2018). The Referendariat lasts at least 12 and at most 24 months and leads to the (Second) State Examination (zweites Staatsexamen). Upon passing this examination, students completed their formal training and can be then seek employment as VET teachers (KMK, 2016).

Because of the wide range of vocational programmes, VET teachers work depending on their vocational subject in schools of different vocational focus. Depending on the vocational speciality of the respective school, they are facing a very heterogeneous group of students. The student body at vocational schools might consists of students without any school-leaving

\footnotetext{
3 In the teacher training is also a third phase consisting of further education and training of teachers.

4 Although the term Referendariat essentially focusses on teacher preparation for higher service, it is wide-spread and often preferred to the broader term Vorbereitungsdienst.
} 
certificate, good graduates of secondary level, graduates holding a university-entry certificate, secondary school dropouts, and/or skilled and experienced professionals. Furthermore, VET teachers should not only be able to convey theoretical content but should also have practical knowledge which they could incorporate into their teaching using examples. So, the spectrum of professional requirements is very broad and considerably more extensive than in all other teaching professions (Frommberger \& Lange, 2018).

\subsection{Number of Students in VET Teacher Training}

Due to the above-mentioned persistent shortage of VET teachers, especially in industrialtechnical fields, it is important to examine all possible reasons for this shortage. One starting point for a root cause analysis consists in the VET teacher training. In all German federal states except Brandenburg, a total of 51 institutions-universities or teacher training colleges-offered VET teacher training with a total of 11,552 enrolled Bachelor students in winter semester 2014/15 (Frommberger \& Lange, 2018). Since 1990/91 the number of programs to become a VET teacher has almost doubled. Their 3,679 newly enrolled VET students present a solid basis for the consecutive Master programs according to Frommberger and Lange (2018). However, only 1,657 of them planned to also obtain a Master degree or a State Examination, a decreasing number compared to the previous year (ibid.). It seems that some students change their mind during their Bachelor studies not wanting to become a VET teacher anymore. Empirically reliable findings on the reasons why are hardly available so far (Lange \& Sülflow, 2017). Hence, one research desideratum is to investigate and understand their motives on why not to follow through with their prospective careers as teachers (Frommberger \& Lange, 2018; KMK, 2011). In order to increase the number of those who complete their teacher training, it is essential to look not only for the causes of students' dropouts but also to investigate the initial motives of current students for choosing a career as a teacher.

\section{Research on Motives for Pre-Service Teachers' Career Choice}

Research on pre-service teachers' career motivation has a long tradition, both nationally (an overview is given in Wiza, 2004) and internationally (Watt et al., 2012). Since teacher training leads almost exclusively to the specific profession of teaching in contrast to more broadbased subjects such as business administration, students take their career decision for this specific career as teachers already at the very beginning of their studies (Spinath et al., 2005). Choosing a career is a developmental process during which a person explores the world of work, aligns them with one's own skills and interests, and acquires facets of career competence, such as planning or stress management skills (Driesel-Lange et al., 2017). One theory to explain teachers' career choice is the expectancy- $\mathrm{X}$-value theory of Eccles et al. (1983; see 
also Pohlmann \& Möller, 2010; Watt \& Richardson, 2007). According to the expectancy-xvalue theory, career choices are directly influenced by factors such as one's abilities, beliefs, and expectancies for success on the one hand, and the value one attaches to the task (of teaching) on the other hand (Retelsdorf \& Möller, 2012). Choosing to become a teacher is most often based on intrinsic, extrinsic and altruistic motivations (Watt et al., 2012), with motivation understood as the "drive that moves people to do something by nature" (Han \& Yin, 2016, p. 3). Examples of motivational reasons include for intrinsic motivation: Interest in the subject or importance of the subject for students, for extrinsic motivation: Job security or a good work-family-balance, and for altruistic motivation: Teaching as a service to society, teaching as a noble profession (Thomson et al., 2012). However, there is no final answer on how to empirically distinguish motivational factors.

Although previous findings are difficult to compare as they differ in terms of sampling, instruments, and methods, one consistent result can be observed across all studies: Intrinsic motivation predominates. The interest or joy of working with children and adolescents is the motivation most often expressed to become a teacher. Regarding other motivations, such as professional interest or feasible work-family-balance, following behind the top position, previous studies offer various, partially conflicting findings (Rothland, 2014). For a more precise view on career choice motivation further comparable results are needed. Therefore, it is important to use theory based, empirical validated instruments.

\subsection{Validated Questionnaires}

Currently, two standardized questionnaires to investigate teachers' career choice motivation that fulfil the above-mentioned criteria exist: The Factors Influencing Teaching Choice Scale (FIT-Choice) by Watt and Richardson (2007) and the Motivation for Choosing Teacher Education Questionnaire (Fragebogen zur Erfassung der Motivation für die Wahl des Lehramtstudiums [FEMOLA]) by Pohlmann and Möller (2010). As both instruments are based on the expectancy-x-value-theory (Eccles et al., 1983) they share some similarities but also differ in some aspect, as described as follows.

Watt and Richardson (2007) developed the FIT-Choice model specially to examine and measure motives of career choice in teacher training. Influencing factors are "Social influences, prior teaching and learning experiences, followed by the more proximal influences of self-perceptions, values, and fallback career. Higher-order constructs . . . are personal utility value and social utility value" (Richardson \& Watt, 2014, p. 7). These motives are operationalized through twelve subscales with a total of 38 items. The FIT-Choice scale was validated in English and afterward translated into different languages to enable international comparisons of career motivation (see the German translation in Watt et al., 2012). Further studies confirmed the factorial structure for the German version. König and Rothland (2013), how- 
ever, found good or acceptable reliabilities only for ten of the twelve subscales. Because of insufficient internal consistencies, Watt et al. (2012) only used selected parts of the instrument to compare the career choice motivation of Australian, American, German, and Norwegian pre-service teachers. Its multilingual availability and validation render FIT-Choice particularly suitable for international comparisons.

In comparison, the FEMOLA questionnaire which originally was developed in German is mainly used for national surveys. With only 32 items it is slightly shorter than the FITChoice. Three of its subscales measure educational interest, subject-specific interest, and utility representing value factors. Further three subscales-ability beliefs, social influences, and low level of difficulty of the course of study-constitute expectancy factors. Three studies confirmed the validity of this factorial structure (Pohlmann \& Möller, 2010).

\subsection{Current Research Results}

Research based on the FIT-Choice questionnaire shows the highest ratings for the five motives intrinsic value, perceived teaching ability, the desire to contribute to the society, to work with children/adolescents, and positive prior teaching and learning experiences. Job security and time for family as extrinsic factors were rated lower but are also important motives. Choosing teacher training as a fallback career is more likely to be rejected (Richardson \& Watt, 2014). International comparisons of Australian, American, German, and Norwegian (Watt et al., 2012), German, Austrian, and Swiss (König et al., 2013), and Finish and German pre-service teachers (Goller et al., 2019) show that their career choice motives across countries have more similarities than differences.

As mentioned above, the questionnaire FEMOLA has been applied exclusively in German-speaking countries. In several studies, for instance from Paulick et al. (2013) or Pohlmann and Möller (2010), educational interest, subject-specific interest and ability beliefs (as intrinsic motives) were rated higher than utility (in some studies divided into family/leisure and financial utility), social influences or a low level of difficulty of the course of study (as extrinsic motives). Retelsdorf and Möller (2012) also compared career choice motivations of pre-service teachers who later will teach at different school types such as elementary school, secondary school, and high academic school track (Gymnasium). Their findings indicate that a strong educational interest is more likely to lead to choosing to become a teacher at an elementary or secondary school. At the same time, people with a higher professional interest are less likely to choose such posts. The stronger the motive utility, the higher is the likelihood of being a teacher at the Gymnasium instead of the elementary school. In addition, a higher belief in ability is associated with a lower probability of choosing an elementary school to teach at, a perceived low difficulty of the course of study however increases this probability. Pohlmann and Möller (2010) also determine a higher level of professional interest and a 
lower assessment of study requirements for teachers at the Gymnasium than for secondary school teachers. As a consequence to those differences, the authors conclude that future research on career choice motivation should extend to other school types of such as vocational schools.

So far only a few studies investigated the career choice motivation of pre-service VET teachers and to what extent might exist differences to the motivation of those pre-service teachers later working at other school types. Müller and Zeitz (2007) conducted a survey with 153 first-year students in VET teacher training at the Technical University of Munich, Germany. According to their findings, which are based on a self-developed instrument, the main career motives were subject-specific interest, educational interest, the proximity to one's own skilled occupation and the desire for personal development.

A Norwegian study examined the career motivation of 195 VET students with the Academic Self-Regulation Scale (SQR-A) which is based on the self-determination theory. The SQR-A comprises four subscales (external regulation, introjected regulation, identified regulation, and intrinsic motivation). The students rated their identified regulation highest, followed by their intrinsic motivation. External regulation was rated lowest. The identified regulation had significantly positive and the external regulation significantly negative correlations with self-efficacy and perceived motivating teaching (Cents-Boonstra et al., 2018). Using the FIT-Choice questionnaire, Berger and Girardet (2015) polled 605 teachers of vocational subjects who either teach full-time or part-time at a vocational school or worked in training workshops or inter-company courses in Switzerland. The results show that similar to primary and secondary school teachers, also VET teachers' career decisions are mainly driven by intrinsic and social motives. One limitation must be kept in mind while interpreting these results: Only a selection of FIT-Choice items was used in the questionnaire. Therefore, it remains unclear whether the strongest motives were identified.

\subsection{Research Question and Hypotheses}

So far there is a paucity of quantitative studies with standardized instruments focusing on the motivation for choosing a career as VET teachers, also compared to other school types. According to a comparative study by Driesel-Lange et al. (2017), students training to become VET teachers show a significantly higher level of career certainty than those to be teaching at the high academic school track (Gymnasium). Compared to their fellow students, for them intrinsic motives and work-family balance were significantly less pronounced motives in their decision to become a teacher. This first comparative study between students who study to become VET teachers and those who will become teachers at a general education school indicate a distinct constellation of career choice motivation of future VET teachers. 
The specific motivational structure of pre-service VET teachers-also in contrast to other pre-service teachers-should be further explored, for example to implement the findings in universities' recruitment strategies for teacher training programs. Our research question which derived from this requirement asks about the differences in terms of career choice motives of students who train to become a VET teacher compared to students who have chosen a career as a teacher at a comprehensive school. Based on the above described previous research, we formulated the following hypotheses: (1) For pre-service VET teachers' intrinsic motives to become a teacher, like subject-specific interest, educational interest, and ability beliefs, are more important than extrinsic motives, like utility, social influences and a low level of difficulty of the course of study. (2) Concerning sociodemographic factors, age is associated with higher utility motives and lower social influences. Prior pedagogical experience is related to higher educational interest. We do not have specific expectations concerning the relation of gender and career choice motives. (3) Compared to students who will teach at comprehensive schools, future VET teachers show a higher subject-specific interest and lower educational interest.

\section{Method}

\subsection{Sample}

The sample consists of $N=79$ pre-service teachers at a German University. Most students were at the beginning of their studies. 30 students (38\%) were enrolled to become VET teachers (i.e. electrical engineering, metal technology, or gardening). 49 students (62\%) will later teach the subject vocational studies/technology (Wirtschaft - Arbeit - Technik [WAT]) at a comprehensive school. Teacher training at university is built the same way for both groups. But upon successful completion of their studies, pre-service VET teachers will receive permission to teach at vocational schools (as part of the VET system), while students who are studying the subject vocational studies/technology will obtain permission to teach at comprehensive schools, mostly at integrated secondary schools ${ }^{5}$ (as part of the general educational system).

We chose this latter group because the subject vocational studies/technology at comprehensive schools has a high share of practical work, for example in metal, electrical or textile workshops and therefore a certain similarity to the contents taught at vocational schools. Regarding their career choice motives, a comparison between those students who choose

\footnotetext{
5 The subject vocational studiestechnology is taught at lower secondary level (until grade 10). With the second general educational subject' which the students choose' they could also teach at high academic school track (Gymnasium).
} 
a practice-oriented subject at a comprehensive school and those students who will teach practice-oriented at a vocational school seems particularly interesting.

The overall sample was $68 \%$ female $(n=54)$ with a mean age of $M=22.90(S D=5.10)$ years. Gender and age proportions differed between the two subsamples: VET students were $50 \%$ female $(n=15)$ and in average $M=23.33(S D=5.28)$ years old. In contrast, the future comprehensive school teachers were $80 \%(n=39)$ female and with a mean age of $M=22.04$ $(S D=3.74)$ years slightly younger. Data were collected during regular classes using a standardized self-report questionnaire. To respond students could choose between a paper-pencil version and an online version.

\subsection{Instruments}

\section{Career Choice Motivation}

Motives to become a teacher were measured using the above described standardized Motivation for Choosing Teacher Education Questionnaire (FEMOLA) including six subscales (Pohlmann \& Möller, 2010; see also Paulick et al., 2013). Students rated each statement on a four-point likert-scale ( $1=$ does not apply at all, $4=$ applies completely), for subscales, number of items, example items, and Cronbach's alpha see Table 1.

Table 1: FEMOLA: Subscales, Number of Items, Example Items, and Cronbach's Alpha

\begin{tabular}{|c|c|c|}
\hline Subscale (N items) & I chose teacher education because ... & $\alpha$ \\
\hline Educational interest (6) & ...I like working with adolescents and young adults. & .81 \\
\hline Subject-specific interest (5) & ...I find the contents of my subjects interesting. & .84 \\
\hline Ability beliefs (5) & ...I think that I am a capable teacher. & .76 \\
\hline Utility (7) & ...I am financially secure as a teacher. & .83 \\
\hline Social influences (5) & ...friends and acquaintances advised me to study as a teacher. & .81 \\
\hline $\begin{array}{l}\text { Low level of difficulty of the } \\
\text { course of study (4) }\end{array}$ & ...it is easier to study as a teacher than other courses of study. & .74 \\
\hline
\end{tabular}

\section{Individual Variables}

We also included students' responses regarding their age in years, their gender $(1=$ female, $2=$ male $)$ and their designated school type $(1=$ comprehensive school, $2=$ vocational school $)$. Furthermore, we asked them to indicate their prior pedagogical experience by checking none, one, or several of eight possible pedagogical activities (i.e. babysitting or tutoring). Those activities were summed up, resulting in a total score of 0 (no prior pedagogical experience) to 8 (experience in eight different pedagogical activities). 


\subsection{Data Analysis}

In a first step, we performed descriptive analyses. In a second step, we examined the distributional differences regarding gender, age, and prior pedagogical experience between the two groups of teacher students. We, therefore, computed a chi-square test with gender and t-tests with age and prior pedagogical experience as variables. In a third step, a multivariate analysis of covariance (MANCOVA) was performed to detect mean differences across the six scales of motivation for choosing teaching education between pre-service VET teachers and future comprehensive school teachers. Gender and prior pedagogical experience were included as covariates in this analysis.

\section{$5 \quad$ Results}

The results of the descriptive statistical analysis are presented in Table 2. The data indicate the highest means for educational interest $(M=3.40, S D=0.42)$ and subject-specific interest $(M=3.34, S D=0.51)$. So, students rated them as their most important motives for choosing the teaching profession. Except of the low level of difficulty of the course of study, all six FEMOLA subscales are on or above the statistical mean of the scale.

The chi-square test confirmed that the two groups significantly differed in terms of gender, $\chi^{2}(1)=6.64, p=.01$, with more women in the comprehensive school group (female $=80 \%$ ) than in the vocational school group (female $=50 \%)$. T-tests showed no significant difference in age distribution between the two student groups, $t(76)=-1.26, p=.21, r=.14$. Students training to become comprehensive school teachers $(M=2.45, S D=1.46)$ had significant more pedagogical experience prior to their studies than VET teacher students $(M=$ $1.67, S D=1.18), t(77)=2.48, p=.02, r=.27$. 
Table 2: Means, Standard Deviations, and Intercorrelations of the Study Variables

\begin{tabular}{|c|c|c|c|c|c|c|c|c|c|c|c|c|}
\hline & & $M$ & $S D$ & 1 & 2 & 3 & 4 & 5 & 6 & 7 & 8 & 9 \\
\hline 1 & Gender & 1.34 & 0.50 & 1 & & & & & & & & \\
\hline 2 & Age & 22.90 & 5.07 & 0.15 & 1 & & & & & & & \\
\hline 3 & Prior pedagogical experience & 2.16 & 1.41 & -0.16 & 0.11 & 1 & & & & & & \\
\hline 4 & Educational interest & 3.41 & 0.43 & -0.00 & -0.08 & 0.05 & 1 & & & & & \\
\hline 5 & Subject-specific interest & 3.34 & 0.52 & -0.09 & -0.05 & -0.02 & $0.34^{* *}$ & 1 & & & & \\
\hline 6 & Ability belief & 3.18 & 0.49 & 0.05 & 0.12 & 0.08 & $0.35^{\star *}$ & $0.22^{*}$ & 1 & & & \\
\hline 7 & Utility & 3.08 & 0.59 & 0.06 & -0.13 & -0.18 & 0.12 & 0.16 & $0.22^{*}$ & 1 & & \\
\hline 8 & Social influences & 2.50 & 0.72 & -0.04 & $-0.34^{\star *}$ & -0.19 & $0.28^{\star *}$ & 0.09 & 0.18 & $0.32^{\star *}$ & 1 & \\
\hline 9 & Low level of difficulty & 1.75 & 0.51 & 0.08 & -0.18 & 0.06 & -0.11 & -0.03 & -0.02 & $0.24^{\star}$ & $0.28^{\star *}$ & 1 \\
\hline
\end{tabular}

Note. $M=$ mean; $S D=$ standard deviation; ${ }^{* *} p<0.001 ;{ }^{* *} p<0.01 ;{ }^{*} p<0.05$; gender: $1=$ female. $2=$ male.

Table 3 displays the mean values of the different motives to become a teacher for both groups. Pre-service VET teachers rated their subject-specific interest $(M=3.35, S D=0.50)$ descriptively in average as their most important motivation for choosing teacher education, followed by their educational interest $(M=3.22, S D=0.45)$ and their ability belief $(M=3.17, S D=0.46)$. In average they attribute the least importance to the low level of difficulty of the course of study $(M=1.69, S D=0.48)$. This confirmed our first hypothesis that the most important motivations of students for choosing to become a VET teacher are intrinsic motives, such as the subject-specific interest (compared to extrinsic motives). 
Table 3: Means and Standard Deviations for the Motivation of Choosing Teacher Education as Function of the School Type While Controlling for Gender and Prior Pedagogical Experience

School type

\begin{tabular}{|c|c|c|c|c|}
\hline \multirow[b]{2}{*}{ FEMOLA } & \multicolumn{2}{|c|}{$\begin{array}{l}\text { Vocational } \\
\qquad(n=30)\end{array}$} & \multicolumn{2}{|c|}{$\begin{array}{l}\text { Comprehensive } \\
\quad(n=49)\end{array}$} \\
\hline & $M$ & $S D$ & $M$ & $S D$ \\
\hline Subject-specific interest & 3.35 & 0.50 & 3.34 & 0.52 \\
\hline Educational interest & 3.22 & 0.45 & 3.51 & 0.37 \\
\hline Ability belief & 3.17 & 0.46 & 3.18 & 0.51 \\
\hline Utility & 2.97 & 0.60 & 3.17 & 0.55 \\
\hline Social influences & 2.13 & 0.59 & 2.69 & 0.65 \\
\hline Low level of difficulty & 1.69 & 0.48 & 1.80 & 0.51 \\
\hline
\end{tabular}

Note. $M=$ mean; $S D=$ standard deviation

Table 4 presents the results of the MANCOVA. Prior to running the MANCOVA, multivariate normality was tested as a necessary condition. As the Kolmogorov-Smirnov test indicated, not all dependent variables demonstrated a normal distribution within the two groups of teacher education. However, this assumption can be discarded under the condition of two approximately equally sized groups in an adequately large sample (Bortz \& Schuster, 2010). The required sample size was estimated from the table of Bortz and Döring (2006, p. 628) and is $N=26$ (for a big effect) for each subgroup. The existence of homogeneity of variance was also checked and validated. As the t-test did not show any statistically significant differences in terms of age between the two teacher education tracks, we did not include age as a covariate in the model.

The results of the MANCOVA show no statistically significant multivariate effects for the covariates gender $(F(6,70)=0.96, p=.46)$ and prior pedagogical experience $(F(6,70)=2.14$, $p=.06)$ thus answering our second hypothesis on their effects on motivations for choosing teacher education. While prior pedagogical experience was not related to higher educational interest and age was not associated with higher utility motives (against our expectations), age showed indeed a negative bivariate relation to social influences (see Table 2). However, the second hypothesis mostly has to be rejected.

Focusing on our third and final hypothesis about possible motivational differences, the following results add to the answer: In contrast to the future VET teachers, students in the track for teaching vocational studies/technology in comprehensive schools descriptevely rated their educational interest $(M=3.51, S D=0.37)$, their subject-specific interest $(M=3.34$, $S D=0.52)$ and the utility, like work-family-balance, $(M=3.17, S D=0.55)$ as the most important motivations for them to become a teacher. In the order of the motivations there already 
consists a difference between the two groups of students, because pre-service VET teachers descriptevely rated their subject-specific interest $(M=3.354, S D=0.50)$ higher than their educational interest $(M=3.22, S D=0.45)$, followed by the ability belief $(M=3.17, S D=0.46)$.

Furthermore, the aspired school type in which the students will later teach has significant effects on the perceived importance of three motivations to become a teacher. Regarding students' educational interest as a motivation to become a teacher, the school type has a medium-sized effect $\left(F(1,75)=9.37, p<.001, \eta^{2}=0.11\right)$. Students in the track for teaching vocational studies/technology in comprehensive schools not only perceive their educational interest as the most vital motivation of all, they also rated it significantly higher than their fellow students in the vocational track did. Thus, as expected in hypothesis 3, future VET teachers reported lower educational interests compared to students for Vocational studies/ technology at comprehensive schools. However, we could not verify the expected higher subject-specific interests in future VET teachers.

Regarding the utility, the two school types have a medium effect on its importance as a motivation to become a teacher, $F(1,75)=4.53, p=.04, \eta^{2}=0.06$. However, for future comprehensive school teachers, it is the third most important motivation for choosing teaching as a career and their rating was significantly higher than that of future VET teachers.

Finally, there is a large effect of the school type regarding social influences as motive to become a teacher, $F(1,75)=19.66, p<.001, \eta^{2}=0.21$. For the future teachers in comprehensive schools, the influences of their social environment were significantly more important than for the future VET teachers.

Table 4: MANCOVA Results for the Effects of the School Type on the Motivation of Choosing Teacher Education While Controlling for Gender and Prior Pedagogical Experience

\begin{tabular}{lccccccccc}
\hline & & Gender & \multicolumn{4}{c}{$\begin{array}{c}\text { Prior pedagogical } \\
\text { experience }\end{array}$} & \multicolumn{3}{c}{ School type } \\
\hline Source & $F$ & $p$ & $\eta^{2}$ & $F$ & $p$ & $\eta^{2}$ & $F$ & $p$ & $\eta^{2}$ \\
\hline Multivariate $(d f=6,70)$ & 0.96 & .46 & .08 & 2.14 & .06 & .15 & 5.51 & .00 & 0.32 \\
\hline Univariate $(d f=1,75)$ & & & & & & & & & \\
Subject-specific interest & 0.94 & .34 & 0.01 & 0.00 & .97 & 0.00 & 0.13 & .72 & 0.00 \\
Educational interest & 0.83 & .37 & 0.01 & 0.00 & .97 & 0.00 & 9.37 & .00 & 0.11 \\
Ability belief & 0.20 & .65 & 0.00 & 1.13 & .29 & 0.01 & 0.01 & .92 & 0.00 \\
Utility & 0.73 & .40 & 0.01 & 2.80 & .10 & 0.04 & 4.53 & .04 & 0.06 \\
Social influences & 0.08 & .78 & 0.00 & 6.86 & .01 & 0.08 & 19.66 & .00 & 0.21 \\
Low level of difficulty & 2.04 & .16 & 0.03 & 0.01 & .94 & 0.00 & 1.61 & .21 & 0.02 \\
\hline Note. $\eta 2$ = partial eta square. & & & & & & & &
\end{tabular}




\section{Discussion and Conclusion}

The purpose of this study was to investigate the career choice motivation of future VET teachers with a validated questionnaire and to compare their motives to those of prospective comprehensive school teachers. The results add to the scarce research on the motivation of pre-service VET teachers and their specificities compared to other pre-service teachers.

All FEMOLA scales, except the level of difficulty of the course of study, have shown a mean above the statistical mean of the scale. They all seem to have mattered in the decision-making process to decide for the course of study. For the future VET teachers subject-specific interest was the most important motive for their career choice, followed by their educational interest. While the subject-specific interest of the comprehensive school teachers showed equal importance, their educational interest was even more important as a career choice motive. Extrinsic motives like utility and social influences were lower in future VET teachers compared to comprehensive school teachers. So, we found significant differences between pre-service VET teachers and vocational studies/technology teachers in comprehensive schools in terms of the motives educational interest, social influences, and utility.

An explanation for the prospective comprehensive school teachers' significantly higher educational interest could lie in the age of their future pupils. In Berlin, the subject vocational studies/technology is taught throughout grade seven to ten at comprehensive schools. Pupils in these classes are therefore in average between 13 and 16 years old, while only $39 \%$ of pupils in vocational schools are 19 years or younger (Autorengruppe Bildungsberichterstattung, 2018). Studies of Retelsdorf and Möller (2012) and others show that educational interest loses of importance as career choice motive with the increasing age of the pupils taught, e.g. in comparison of elementary and secondary schools with the Gymnasium.

The lower degree of the perceived social influence as a motivational trigger to become a VET teacher could possibly be explained by a low level of awareness of the VET teaching profession (Frommberger \& Lange, 2018) compared with the general teaching profession. Since this occupation is little known, its probability to be recommended by friends or family is comparatively lower than that of teaching in general schools. Further, depending on economic development, social influence to become a VET teacher might differ: In times of a rather sound economy (at the time of the survey), friends and family might be less inclined to propose the teacher profession compared to times of economic downturn, where becoming a teacher could seem as a more secure job opportunity which could be more often recommended by the social environment.

A possible explanation for the differences in the motive utility (with a medium but significant effect size) could be the observed gender difference between the two sample groups. The comprehensive school sample has a significantly higher proportion of women than the vocational school group. It might therefore be possible that aspects such the work-family compatibility play a more important role for female than for male students. The general framework 
for teachers in Germany is characterized by a high degree of reliability and certainty. For example, teachers receive a decent salary and pension, have an above-average number of holidays, and are entitled by law to switch to part-time upon their request (Füssel, 2014). Even if it is presuming old role models, a guaranty to be able to return to their original job after a pregnancy could weight importantly in a women's career decision, maybe more importantly than for a man.

\subsection{Conclusions and Practical Implications}

An important theoretical implication of the current study is that VET teacher students are indeed a special subgroup of teacher training students with a differential pattern of career choice motivation. The subject specific interest was the most important motivation for choosing teacher education, followed by educational interest, while social influences and utility were comparably far less important. As shown for other types of teacher training students like elementary school versus high academic school track (Gymnasium) teachers (Retelsdorf \& Möller, 2012), VET teacher students differ in their career choice motives. Against the backdrop of the paucity of research on this group of teachers and the light of the teacher shortage especially in vocational schools, more empirical studies on VET teachers seem highly recommendable.

Practical implications derive from the findings on the different motivations of the preservice teachers. One implication is that our knowledge on their career choice motivations could be applied in the recruitment strategies of universities to increase the number of students who become teachers at vocational schools. Adapted recruiting and communication strategies could incorporate career choice motives to promote the profession of vocational school teacher. Through the motivation of passing on one's own specialist knowledge, for example, it would be possible to specifically address professionals who are looking for a career change or who are interested in continuing career development. In counteracting the shortage of teaching staff at vocational schools, not only must more students be recruited, but the conditions for a successful course of study and for remaining in the teaching profession later must also be ensured. Again, career choice motivation offers a valuable starting point for the initial counselling of prospective students in order to convey a realistic picture of their studies and everyday working life as teachers which then can be compared with the career choice motives of the prospective students.

Because we surveyed pre-service teachers, results may not be directly transferred to VET in-service teachers. However, their motives to become VET teachers may prolong to later occupancy at VET schools. Considering motivating and demotivating features of the working environment and the initial motives also could further evolve (Han \& Yin, 2016). The analysis of changing and enduring motives to teach, starting with of pre-service teachers to con- 
tinued education in the Referendariat to in-service teachers at VET schools is due to future research, both cross-sectional and longitudinal. Independently from this, students should be prepared in the best way in their studies for the challenging job as VET teachers in order to keep them in the teaching profession permanently.

\subsection{Limitations and Future Research}

Although this study provides valuable insights into career choice motivation of pre-service VET teachers, some limits must be acknowledged when interpreting its results. First, our sample was comparatively small due to the low number of students in the VET teacher program at the participating university and with this sample size we could only prove big effects. We are dealing here with a general problem in researching the profession of VET teaching. In addition, our aim was to measure students' career choice motivation at the beginning of their studies which further reduced the available number of prospective participants. Therefore, concerted initiatives to further research career choice motivation across universities are of particular importance in the future.

Second, the group of pre-service vocational studies/technology teachers constitutes a representative comparative group for general schools only to a limited extent. On the one hand, the subject of instruction includes a broad spectrum of subjects ranging from nutritional science to metalwork and vocational orientation, so that vocational studies/technology teachers have a broader range of content than teachers of other subjects at general schools. On the other hand, the subject contains many elements of practical work, for example in textile, carpentry or electrical workshops. Hence, the teaching activities of vocational studies/ technology teachers have a stronger practical focus than that of other subjects at general schools. Because of the practical activities, vocational studies/technology teachers could in terms of their career choice motivation be closer to VET teachers than other subject teachers in comprehensive schools.

The third constraint results from the cross-sectional design of our data which allows no conclusions about possible changes in terms of the perception of one's initial career choice motivation. Future research might examine whether the framing of one's initial career choice motivation may change in the course of one's studies (e.g., between the beginning of the Bachelor's program and the Master's program). Ideally, students of the same cohort would be interviewed several times over the course of their studies in order to assess possible changes in their perception of their initial motivation to become a teacher. It is also of interest weather and how practical training might affect it. A hypothesis in this respect would be that with the increase in pedagogical knowledge and on-the-job experience through the obligatory internships, students will increasingly adopt the role of teachers for themselves. In the retrospective 
assessment, the extrinsic motives could thus recede further into the background in favour of the intrinsic motives as central career choice motives.

Forth, the last limitation is due to the fact that our analyses are based on retrospective self-assessments, which in general entail the risk of socially desirable responding. According to Paulhus (1984), respondents embellish their own answers towards socially accepted views in order to appear in a better light towards themselves and/or third parties. In the present case, extrinsic motives, such as the high compatibility of the teaching profession with family obligations or job security, might have been rated as less important than they were in the decision-making process. Respondents might feel that in society extrinsic motives are considered as less noble and contradict the public opinion on why someone should want to become a teacher. The same reasons may have led to a stronger evaluation of the intrinsic motives.

Taking these considerations into account, we believe that the current study offers new and relevant insights into the career choice motivation of pre-service VET teachers. Their high subject-specific interest, combined with educational interest on the one hand and their comparably low utility and social influence as career choice motivations on the other hand, lay a solid motivational foundation for studying to become future VET teachers. Gaining more motivated per-service VET teachers and preparing them with the necessary knowledge, abilities and attitudes in the course of their studies presents a good starting point to reduce the teacher shortage in an important area in our educational system-the vocational schools.

\section{References}

Autorengruppe Bildungsberichterstattung. (2018). Bildung in Deutschland 2018. Ein indikatorengestützter Bericht mit einer Analyse zu Wirkungen und Erträgen von Bildung [Education in Germany 2018, an indicator-based report with an analysis of the effects and returns of education]. Bildungsbericht. https://www.bildungsbericht.de/de/bildungsberichte-seit-2006/bildungsbericht-2018/ pdf-bildungsbericht-2018/tabellenanhang-2018.pdf

Berger, J.-L., \& Girardet, C. (2015). The determinants of VET educators' occupational choice. Education + Training, 57(1), 108-126. https://doi.org/10.1108/ET-04-2013-0062

Bertelsmann Stiftung. (2017). Schüler-Boom: Zehntausende zusätzliche Lehrer und Klassenräume notwendig. Pressemeldung 12.07.2017 [Student boom: Tens of thousands of additional teachers and classrooms needed. Press release 12.07.2017]. Bertelsmannstiftung. https://www.bertelsmannstiftung.de/de/presse/pressemitteilungen/pressemitteilung/pid/schueler-boom-zehntausende-zusaetzliche-lehrer-und-klassenraeume-notwendig

Federal Institute for Vocational Education and Training. (2018). Bekanntmachung des Verzeichnisses der anerkannten Ausbildungsberufe und des Verzeichnisses der zuständigen Stellen vom 19. Juni 2018 [Publication of the list of recognised training occupations and the list of competent bodies of 19 June 2018]. BIBB. https://www.bibb.de/verzeichnis-ausbildungsberufe 
Blaß, K., \& Himmelrath, A. (2016). Berufsschulen auf dem Abstellgleis. Wie wir unser Ausbildungssystem retten können [Vocational schools on a siding. How we can save our education system]. Edition Körber.

Bortz, J., \& Döring, N. (2006). Forschungsmethoden und Evaluation. Für Human- und Sozialwissenschaftler [Research methods and evaluation. For human and social scientists] (4th ed.). Springer Medizin.

Bortz, J., \& Schuster, C. (2010). Statistik für Human- und Sozialwissenschaftler [Statistics for human and social scientists] (7th ed.). Springer. https://doi.org/10.1007/978-3-642-12770-0

Cents-Boonstra, M., Lichtwarck-Aschoff, A., Denessen, E., Haerens, L., \& Aelterman, N. (2018). Identifying motivational profiles among VET students: differences in self-efficacy, test anxiety and perceived motivating teaching. Journal of Vocational Education \& Training, 23, 1-23. https://doi.org/ 10.1080/13636820.2018.1549092

Driesel-Lange, K., Morgenstern, I., \& Keune, M. (2017). Wer wird Lehrer/in am Berufskolleg? Die Unterstützung von Professionalisierungsprozessen angehender Lehrpersonen für die Berufsbildung [Who becomes a teacher at the vocational college? The support of professionalisation processes of prospective teachers for vocational education and training]. In M. Becker, C. Dittmann, J. Gillen, S. Hiestand \& R. Meyer (Hrsg.), Einheit und Differenz in den gewerblich-technischen Wissenschaften. Berufspädagogik, Fachdidaktiken und Fachwissenschaften (Bildung und Arbeitswelt, 33, pp. 368387). LIT Verlag.

Eccles, J., Adler, T. F., Futterman, R., Goff, S. B., Kaczala, C. M., Meece, J. L., \& Midgley, C. (1983). Expectancies, values, and academic behaviors. In J. T. Spence (Ed.), Achievement and achievement motivation. Psychological and sociological approaches (pp. 75-146). W. H. Freeman.

European Centre for the Development of Vocational Training (2017). The changing nature and role of vocational education and training in Europe. Volume 2: Results of a survey among European VET experts (Cedefop research paper, Bd. 64). Publications Office. https://doi.org/10.2801/548024

Frommberger, D., \& Lange, S. (2018). Zur Ausbildung von Lehrkräften für berufsbildende Schulen. Befunde und Entwicklungsperspektiven [For the training of teachers for vocational schools. Findings and development perspectives]. Working Paper Forschungsförderung, 60.

Füssel, H.-P. (2014). Rechtsstellung, Laufbahnen und Besoldung der Lehrkräfte [Legal status, careers and salaries of teachers]. In E. Terhart, H. Bennewitz \& M. Rothland (Eds.), Handbuch der Forschung zum Lehrerberuf [Teaching profession research manual] (pp. 123-143). Waxmann.

Goller, M., Ursin, J., Vähäsantanen, K., Festner, D., \& Harteis, C. (2019). Finnish and German student teachers' motivations for choosing teaching as a career. The first application of the FITChoice scale in Finland. Teaching and Teacher Education, 85, 235-248. https://doi.org/10.1016/j. tate.2019.06.023

Hattie, J. (2009). Visible learning: A synthesis of over 800 meta-analyses relating to achievement. Routledge.

Han, J., \& Yin, H. (2016). Teacher motivation: Definition, research development and implications for teachers. Cogent Education, 3(1), 1217819. https://doi.org/10.1080/2331186X.2016.1217819

Hensen, K. A., \& Hippach-Schneider, U. (2016). Supporting teachers and trainers for successful reforms and quality of vocational education and training: mapping their professional development in the EUGermany (Cedefop ReferNet thematic perspectives series). Cedefop. http://libserver.cedefop.europa.eu/vetelib/2016/ReferNet_DE_TT.pdf 
Hippach-Schneider, U., \& Huismann, A. (2019). Vocational education and training in Europe - Germany. Cedefop ReferNet VET in Europe reports 2018. Cedefop. https://cumulus.cedefop.europa.eu/files/ vetelib/2019/Vocational_Education_Training_Europe_Germany_2018_Cedefop_ReferNet.pdf

Huismann, A. (2018). Cedefop European Public opinion survey on vocational education and training, country overview: Germany. Cedefop ReferNet thematic perspectives series. Cedefop. https://cumulus.cedefop.europa.eu/files/vetelib/2018/opinion_survey_VET_Germany_Cedefop_ReferNet. pdf

Klemm, K. (2018). Dringend gesucht: Berufsschullehrer. Die Entwicklung des Einstellungsbedarfs in den beruflichen Schulen in Deutschland zwischen 2016 und 2035 [Urgently wanted: Vocational school teacher. The development of recruitment needs in vocational schools in Germany between 2016 and 2035]. Bertelsmann Stiftung. https://doi.org/10.11586/2018042

Kultusministerkonferenz. (2011). Lehrereinstellungsbedarf und Lehrereinstellungsangebot in der Bundesrepublik Deutschland. Modellrechnung 2010 - 2020 [Teacher recruitment needs and supply in the Federal Republic of Germany. Model calculation 2010 - 2020]. https://www.kmk.org/fileadmin/Dateien/pdf/Statistik/BERICHT_MODELLRECHNUNG_online.pdf

Kultusministerkonferenz. (2016). Rahmenvereinbarung über die Ausbildung und Prüfung für ein Lehramt der Sekundarstufe II (berufliche Fächer) oder für die beruflichen Schulen (Lehramtstyp 5) [Framework agreement on the training and examination for a secondary school teacher (vocational subjects) or for vocational schools (type 5)]. https://www.kmk.org/fileadmin/Dateien/veroeffentlichungen_beschluesse/1995/1995_05_12-RV-Lehramtstyp-5.pdf

König, J., \& Rothland, M. (2013). Pädagogisches Wissen und berufsspezifische Motivation am Anfang der Lehrerausbildung. Zum Verhältnis von kognitiven und nicht-kognitiven Eingangsmerkmalen [Pedagogical knowledge and job-specific motivation at the beginning of teacher training. The relationship between cognitive and non-cognitive input characteristics]. Zeitschrift für Pädagogik, 59(1), 43-65.

König, J., Rothland, M., Darge, K., Lünnemann, M., \& Tachtsoglou, S. (2013). Erfassung und Struktur berufswahlrelevanter Faktoren für die Lehrerausbildung und den Lehrerberuf in Deutschland, Österreich und der Schweiz [Recording and structure of factors relevant to career choice for teacher training and the teaching profession in Germany, Austria and Switzerland]. Zeitschrift für Erziehungswissenschaft, 16(3), 553-577. https://doi.org/10.1007/s11618-013-0373-5

Lange, S., \& Sülflow, A. (2017). Aktuelle Entwicklungen der Studierendenzahlen in beruflichen Lehramtsstudiengängen: Verlieren wir zu viele Studierende im Übergang vom Bachelor- in das Masterstudium? [Current developments in student numbers in professional teacher training courses: Are we losing too many students in the transition from bachelor's to master's degree programmes?]. Die berufsbildende Schule, 69(2), 65-71.

Müller, M., \& Zeitz, U. (2007). Entscheidungskriterien von Studienanfängern/-innen für Studiengänge für ein Lehramt an beruflichen Schulen [Decision criteria of first-year students for courses of study for a teaching profession at vocational schools]. Die berufsbildende Schule, 59(10), 281-286. https:// doi.org/10.3278/6004660w185

Paulick, I., Retelsdorf, J., \& Möller, J. (2013). Motivation for choosing teacher education. Associations with teachers' achievement goals and instructional practices. International Journal of Educational Research, 61, 60-70. https://doi.org/10.1016/j.ijer.2013.04.001

Paulhus, D. L. (1984). Two-component models of socially desirable responding. Journal of personality and social psychology, 46(3), 598-609. https://doi.org/10.1037/0022-3514.46.3.598 
Pohlmann, B., \& Möller, J. (2010). Fragebogen zur Erfassung der Motivation für die Wahl des Lehramtsstudiums (FEMOLA) [Questionnaire to record the motivation for choosing a teacher training course]. Zeitschrift für Pädagogische Psychologie, 24(1), 73-84. https://doi.org/10.1024/1010-0652/ a000005

Retelsdorf, J., \& Möller, J. (2012). Grundschule oder Gymnasium? Zur Motivation ein Lehramt zu studieren [Primary school or high school? The motivation to study a teaching profession]. Zeitschrift für Pädagogische Psychologie, 26(1), 5-17. https://doi.org/10.1024/1010-0652/a000056

Richardson, P. W., \& Watt, H. M. G. (2014). Why People choose teaching as a career. An expectancyvalue approach to understanding teacher motivation. In P. W. Richardson, S. A. Karabenick, \& H. M. G. Watt (Eds.), Teacher motivation. Theory and practice (pp. 3-19). Routledge.

Rothland, M. (2014). Warum entscheiden sich Studierende für den Lehrerberuf [Why do students decide to become teachers]? In E. Terhart, H. Bennewitz, \& M. Rothland (Eds.), Handbuch der Forschung zum Lehrerberuf [Teaching profession research manual] (2nd ed., pp. 349-385). Waxmann.

Spinath, B., van Ophuysen, S., \& Heise, E. (2005). Individuelle Voraussetzungen von Studierenden zu Studienbeginn: Sind Lehramtsstudierende so schlecht wie ihr Ruf [Individual requirements of students at the beginning of their studies: Are teacher training students as bad as their reputation]? Psychologie in Erziehung und Unterricht, 52(3), 186-197.

Stellmacher, A., Huck, J., \& Ophardt, D. (2019). Ergebnisse der Erstsemesterbefragung der Lehramtsstudierenden der Technischen Universität Berlin. Vergleich der Erhebung des Wintersemesters 2018/19 mit der des Wintersemesters 2017/18 [Results of the first semester survey of student teachers at the Technische Universität Berlin. Comparison of the survey of the winter semester 2018/19 with that of the winter semester 2017/18]. Technische Universität Berlin. https://doi.org/10.14279/depositonce- 8580

Thomson, M. M., Turner, J. E., \& Nietfeld, J. L. (2012). A typological approach to investigate the teaching career decision: Motivations and beliefs about teaching of prospective teacher candidates. Teaching and Teacher Education, 28(3), 324-335. https://doi.org/10.1016/j.tate.2011.10.007

Watt, H. M. G., \& Richardson, P. W. (2007). Motivational factors influencing teaching as a career choice: Development and validation of the FIT-choice scale. The Journal of Experimental Education, 75(3), 167-202.

Watt, H. M. G., Richardson, P. W., Klusmann, U., Kunter, M., Beyer, B., Trautwein, U., Baumert, J. (2012). Motivations for choosing teaching as a career. An international comparison using the FIT-Choice scale. Teaching and Teacher Education, 28(6), 791-805. https://doi.org/10.1016/j. tate.2012.03.003

Wenström, S., Uusiautti, S., \& Määttä, K. (2018). "The Force that Keeps you Going": Enthusiasm in Vocational Education and Training (VET) Teachers' Work. International Journal for Research in Vocational Education and Training, 5(4), 244-263. https://doi.org/10.13152/IJRVET.5.4.1

Wiza, S. (2014). Motive für die Studien- und Berufswahl von Lehramtsstudierenden: Eine qualitative Wiederholungsmessung [Motives for the study and career choice of student teachers: A qualitative repeat measurement]. Dissertation. University Duisburg-Essen. 


\section{Biographical Notes}

Anne Stellmacher (née Micknaß) is a researcher and $\mathrm{PhD}$ student at the Institute of Education, Department of Educational Psychology at the Technische Universität Berlin, Germany. Her PhD project focuses the career choice motivation of pre-service vocational school teachers and relates it to the teacher decision certainty, teacher competencies, and teacher self-efficacy. Another focus of her work is the evaluation of teacher training programs and the question of reasons for possible dropouts.

Svenja Ohlemann is a researcher at the Institute of Education, Department of Educational Psychology at the Technische Universität Berlin, Germany. Her research focuses on diversity and individual needs relating to career development, competence development, motivation and decision-making. Her research interests also cover career aspirations, teacher training, and promoting and supporting the development of interests and talents in childhood and adolescence.

Prof Dr Jan Pfetsch is guest professor and deputy head of the Department of Educational Psychology, Institute of Education, Technische Universität Berlin, Germany. His current research interests cover development of competencies in teacher training (esp. diagnostic competence), learning with digital media, gendered interest in STEM, and aggressive and prosocial behaviour in children and adolescents (especially cyberbullying).

Prof Dr Angela Ittel is the head of the Department of Educational Psychology and Vice President for Strategic Development, Junior Scholars, and Teacher Education at the Technische Universität Berlin, Germany. 